\section{儿童友好型城市建设背景下 景观设计师的职责和角色转变 RESPONSIBILITIES AND ROLES OF LANDSCAPE ARCHITECTS IN THE ESTABLISHMENT OF CHILD FRIENDLY CITY}

1 引言

\section{1 儿童权利和城市发展}

儿童参与城市设计和空间决策的理念始见于 20 世纪 60 年代，当时 美国城市研究者雪莉 $\cdot R \cdot$ 阿尔斯坦 ${ }^{[1]}$ 和保罗 $\cdot$ 戴维多夫 ${ }^{[2]}$ 曾广泛呼吁 “公众参与” 在城市建设中的重要性，对后来将儿童使用者的意见纳 人设计过程起到了重要的推动作用。1987年, MIG设计事务所的三位创 始人一罗宾 $\cdot$ 莫尔、苏珊 - 戈尔茨曼和丹尼尔 $\cdot$ 艾克法诺——合作

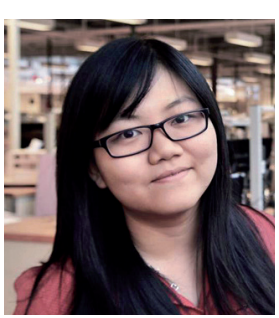

\title{
黄伊伟
}

美国加利福尼亚大学戴维斯分校人类生态学系地理学博士候选人

HUANG Yiwei*

PhD Candidate of Geography, Department of Human Ecology, University of California Davis

"Corresponding Author

ess: Hunt 161, One Shiel

Email: yiwhuang@ucdavis.edu

摘要

在“儿童友好型城市倡议”发起20余载后, 中国景观设计行业的相关实践进展依然较为缓 慢，建成的儿童活动空间与儿童友好型城市的愿 景仍存在一定差距。本文指出，导致这一问题的 原因包括: 1) 儿童作为这些项目的核心使用者, 未能充分参与设计过程, 致使其真实需求并未反 映在设计方案中；2）目前的城市儿童景观设计主 要围绕独立项目进行设计定位和概念提炼, 缺乏 从文化和社会层面对整个城市儿童活动空间系统 及其对儿童产生的影响进行综合考量。对此，本 文提出, 景观设计师可从生态系统理论和公众参 与理论中获得启发, 积极拓展自身在未来儿童友 好型城市营造中的职责。最后, 本文通过介绍美 国“成长在博尔德”计划、英国伦敦的“游乐和 非正式娱乐”策略，以及美国绿色校园三个国际 案例，阐明景观设计师在儿童友好型城市的建设 中不仅仅是设计策略的制定者, 亦可充当利益相 关方的协调者和参与式设计项目的发起者; 景观 设计师的工作也不应限于传统的儿童游乐空间设 计，而应更加关注社区和整个城市的空间格局， 以推动整个社会对儿童权利的重视, 最终完成城 市空间的串联、整合与整体提升。

\section{关键词}

儿童友好型城市; 城市空间; 生态系统理论; 公众 参与; 参与式设计；景观设计；社会职责

编辑 王胤瑜 翻译 黄伊伟 王胤瑜 田乐

EDITED BY WANG Yinyu TRANSLATED BY HUANG Yiwei WANG Yinyu Tina TIAN

\section{ABSTRACT}

More than 20 years have passed since the launch of the Child Friendly Cities Initiative. However, relevant practices in China are still insufficient and laggard. This article concludes two reasons: 1) children participation in the design process is far insufficient and results in the failure of the expression of core users' demands; and 2) landscape architects less think of the holism of such children spaces at a city scale with considerations on city's cultural identity and societal backdrops, and also ignore the influence of such places on children's development. With these problems in mind, this article proposes that landscape architects can draw inspiration from the Ecological Systems Theory and Public Participation Theory, actively expanding their responsibilities in the establishment of Child Friendly City. Following that, three international case studies, namely Growing Up Boulder Initiative, Play and Informal Recreation Strategy of London, and Green Schoolyard America, are introduced to demonstrate that landscape architects should not just design proposals, but act as coordinators among different parties and leaders of innovative urban space renovation. As the integrator of the urban spatial framework landscape architects should go beyond the design of individual playgrounds and focus on improving community environment and the spatial pattern of the whole city, in order to protect child rights and to realize integration and improvement of urban spaces.

\section{KEYWORDS}

Child Friendly City; Urban Space; Ecological Systems Theory; Public Participation;

Participatory Design; Landscape Architecture; Social Responsibilities 
出版了《儿童游乐指南: 儿童户外游乐设施的规划、设计和管理》 ${ }^{[3]}$, 首次提出了建造普适性户外游乐空间的方法。1989年，《联合国儿童 权利公约》正式发布，传递了 “儿童是拥有完整自身权利的人，他们 并非其父母的归属品, 也不是任何决定的被动接受者” 的理念 ${ }^{[4]}$ 。1994 年，世界自然基金会 (WWF) 在意大利博洛尼亚举行了 “夺回我们的 城市” 主题会议, 邀请了来自意大利 100 所学校的 300 名儿童参会, 并 发布了《儿童宣言: 如何夺回我们的城市》 ${ }^{[5]}$, 将儿童对城市的最基本 期望概括为: 总体期望、对城市的期望、对绿地的期望、对学校的期 望, 应对交通拥挤的期望, 以及对未来的期望。1996年, 联合国儿童 基金会正式发出 “儿童友好型城市倡议” ，明确提出儿童的福祉是衡 量城市健康、社会民主和治理水平的关键指标, 并完善了儿童在成长 中所应获得的各种权利保障, 包括健康卫生、教育、住所、安全、人 身保护，以及正常参与家庭、社区及社会生活 ${ }^{[6]}$ 。

诚然, 儿童友好型城市的建设有赖于完善的政策与法律支持, 但 也有许多目标与社会发展和城市空间建设息息相关，例如 “可独自在 街道上安全行走” ，拥有 “未受污染的环境和绿色空间” 和 “与朋友 见面和玩要” 的场地, 以及 “参与文化和社会活动, 成为拥有平等地 位的公民” 等 ${ }^{[7]}$ 。其中, “平等和尊重” 是一个极其重要的议题, 也是 当前中国户外游乐空间建设中一个容易被忽视的部分。目前中国绝大 多数游乐场和儿童公园的设计建造仅考虑安全性和视觉效果, 对鼓励 儿童自主探索城市空间、树立社会角色意识并无助益。

\section{2 中国城市儿童景观设计现状}

目前, 中国面向儿童的城市景观设计主要依托其他空间建设项目 进行, 即设计师直接受政府或开发商委托, 在城市公共空间或者居住

\section{Introduction}

\subsection{Child Rights and Urban Development}

Globally, children's participation in urban design and decisionmaking can be traced in as early as the 1960s, when U.S. urban researchers Sherry R. Arnstein ${ }^{[1]}$ and Paul Davidoff ${ }^{[2]}$ widely publicized the importance of public participation in urban redevelopment, significantly promoting children's participation in urban design process. In 1987, Robin Moore, Susan Goltsman, and Daniel Iacofano, three founders of MIG, co-published Play for All Guidelines: Planning, Designing, and Management of Outdoor Play Settings for All Children ${ }^{[3]}$, first proposing ways to build outdoor places where everyone can play. In 1989, the United Nations Convention on the Rights of the Child (UNCRC) was formally released, stating that "children are not just objects who belong to their parents and for whom decisions are made, or adults in training. Rather, they are human beings and individuals with their own rights." ${ }^{[4]} \mathrm{In}$ 1994, WWF held Children's Congress in Bologna, Italy, inviting 300 children from 100 schools across the country and published The Children's Manifesto: How to Win Back Our Cities, which proposed children' general needs for city and elaborated them as expectations of cities, schools, urban green spaces, safe traffic environments, and the future ${ }^{[5]}$. In 1996, the Child Friendly Cities Initiative was officially launched, stating children's wellbeing as a key indicator for measuring a city's health level, democracy, and governance, and claiming all the indispensable rights to children's growth - health and hygiene, education, shelter, safety, personal protection, and participation in family, community, and social life ${ }^{[6]}$.

Besides a solid foundation of policy and legislation, the establishment of Child Friendly City (CFC) also requires social advance and spatial improvement. As UNICEF proposes, in a CFC children can "walk alone on the street safely," have an "unpolluted and green space environment," "meet and play with friends," "participate in cultural and social activities to become equal citizens," and so on ${ }^{[7]}$. Among such goals, "equality" and "being respected" are two fundamental aspects but often overlooked in the construction of outdoor play space in China. Currently, most playgrounds in China are simply designed with considerations on safety and visual attraction, failing to inspire children's exploratory behaviors into the physical world and their own social identity.

1.2 The Status of Landscape Design for Children in Chinese Cities

At present, most landscape projects designed for children in China are subordinate to other government-commissioned or commercial urban development, where landscape architects 
区内，依据规划指标设计建造儿童活动空间。这一设计模式高度依赖 于设计师的个人专业技能和甲方的主观认知水平, 设计内容受限于上 位规划框架，一方面造成不同区域、不同投资规模的儿童景观空间品 质差异巨大，另一方面导致设计手法和风格、空间功能和设施雷同。 这一问题的本质在于1) 此类空间真正的使用者一一童一一未能充分 参与项目设计过程, 致使其真实需求并未反映在设计方案中；2）目 前设计师在儿童景观设计中主要围绕独立项目进行设计定位和概念提 炼, 缺乏从文化和社会层面对整个城市儿童活动空间系统及其对儿童 产生的影响进行综合考量 (图1)。若能在设计过程中引入儿童参与, 不仅能够增强项目的独特性, 也有利于提高儿童的社交活动参与度, 使项目对儿童的影响不仅仅限于游乐设施本身; 另一方面, 景观设计 师应从设计单一的儿童活动空间转向探索整个城市空间脉络对儿童发 展的综合性影响, 以实现自身角色的提升。

\section{2 生态系统理论及公众参与理论的启示}

\section{1 生态系统理论}

在很长一段时间内, 欧美学者都沿用生物医学模型研究人类的健 康状况, 认为疾病仅由生物学因素引起。1977年, 乔治 $\cdot \mathrm{L} \cdot$ 恩格尔打 破了这一观念, 并提出生物学因素、社会因素, 以及个人心理和体验 共同决定了个体面对疾病的脆弱程度 ${ }^{[8]}$ 。而尤里 - 布朗芬布伦纳进一 步将人类成长的影响因子分成 4 个逐级嵌套、相互影响的系统——微系 统、中系统、外系统, 以及宏系统; 随后又补充了 “时间” 这一影响 因子, 称之为 “时间系统”, 形成了 “生态系统理论” ${ }^{[9]}$ (图2)。

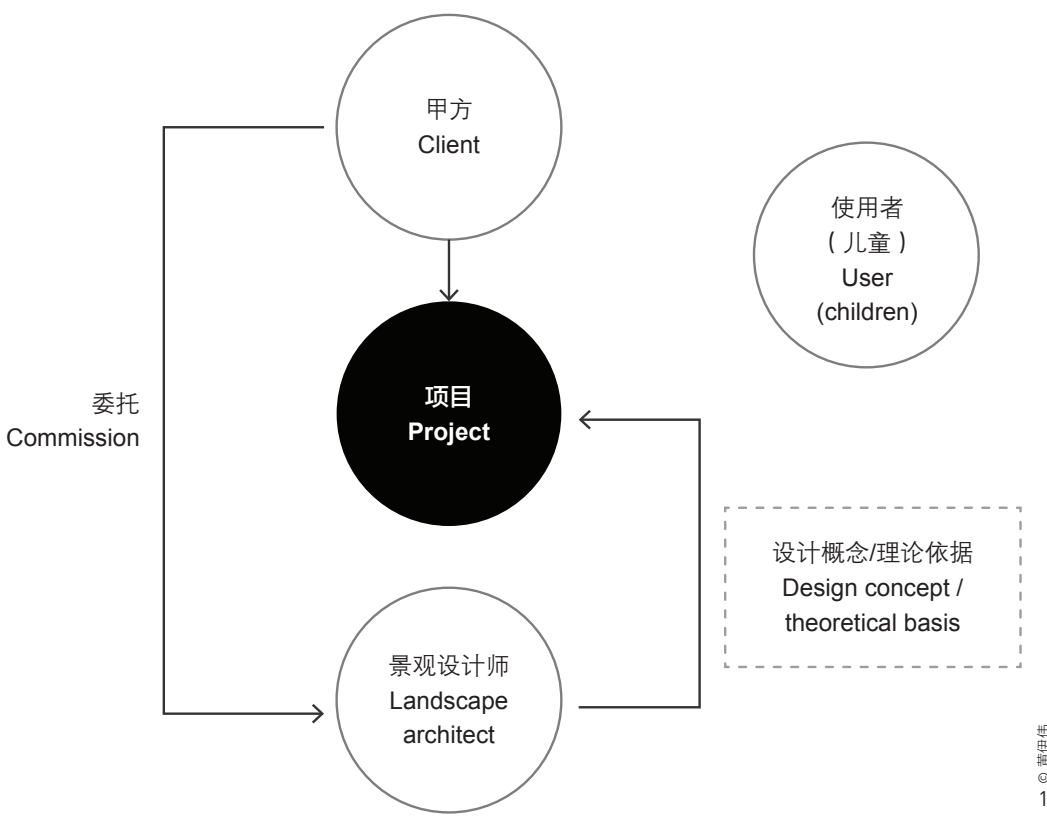

are asked to design playgrounds in public spaces or residential communities with rigid planning and design restrictions. The design quality of such children activity places are largely defined by designers' expertise and by clients' specific demands, as well as the disparity in investment and locality, but witnessing monotony in design methods, visual features, and functionality. This is because 1) children, the core users to such places, are absent in the design processes, whose needs are not fully understood and responded to; and 2) landscape architects less think of the holism of such children spaces at a city scale with considerations on city's cultural identity and societal backdrops, and also ignore the influence of such places on children's development (Fig. 1). Therefore, children's participation should be more emphasized in landscape design process to enhance the uniqueness of the projects and enrich children's social experience. Also, landscape architects should put more efforts in building an urban system of children spaces so as to expand their role for contemporary social needs.

\section{Inspirations from the Ecological Systems Theory and Public Participation Theory}

\subsection{Ecological Systems Theory}

For a long period, European and American researchers employed bio-medical models to study children's growth and health, holding that diseases are only caused by biological factors. In 1977, George L. Engal challenged this dogmatism by proposing that biological factors, society, and personal psychology and experience jointly determine a person's vulnerability to diseases ${ }^{[8]}$. Then Urie Bronfenbrenner came up with the Ecological Systems Theory, a multi-sphere system dividing the impact factors on human development into the micro system, mesosystem, exosystem, and macro system. Later he completed the theory by adding the choronosystem ${ }^{[9]}$ (Fig. 2).

According to the Ecological Systems Theory, the micro system for children refers to the factors directly sharping their living environment, including family members, classmates, friends, and the common landscapes in their daily life such as activity spaces in community. The mesosystem refers to the interaction and relationship between various factors of the micro system (e.g., where a child studies depends on where he / she lives, and what kind of peers he / she has depends on the environment of his / her neighborhood). The exosystem, consisting of local culture, medical services, accessibility of park systems, community services, etc., associated with all factors of the micro system and the mesosystem thus influencing the individual indirectly. The macro system refers to the social and
1. 现阶段中国城市儿童 景观项目的开展模 式, 儿童尚未参与到 设计过程中。

1. The existing work pattern of urban landscape design for children in China. Children are excluded from the design process of such places. 


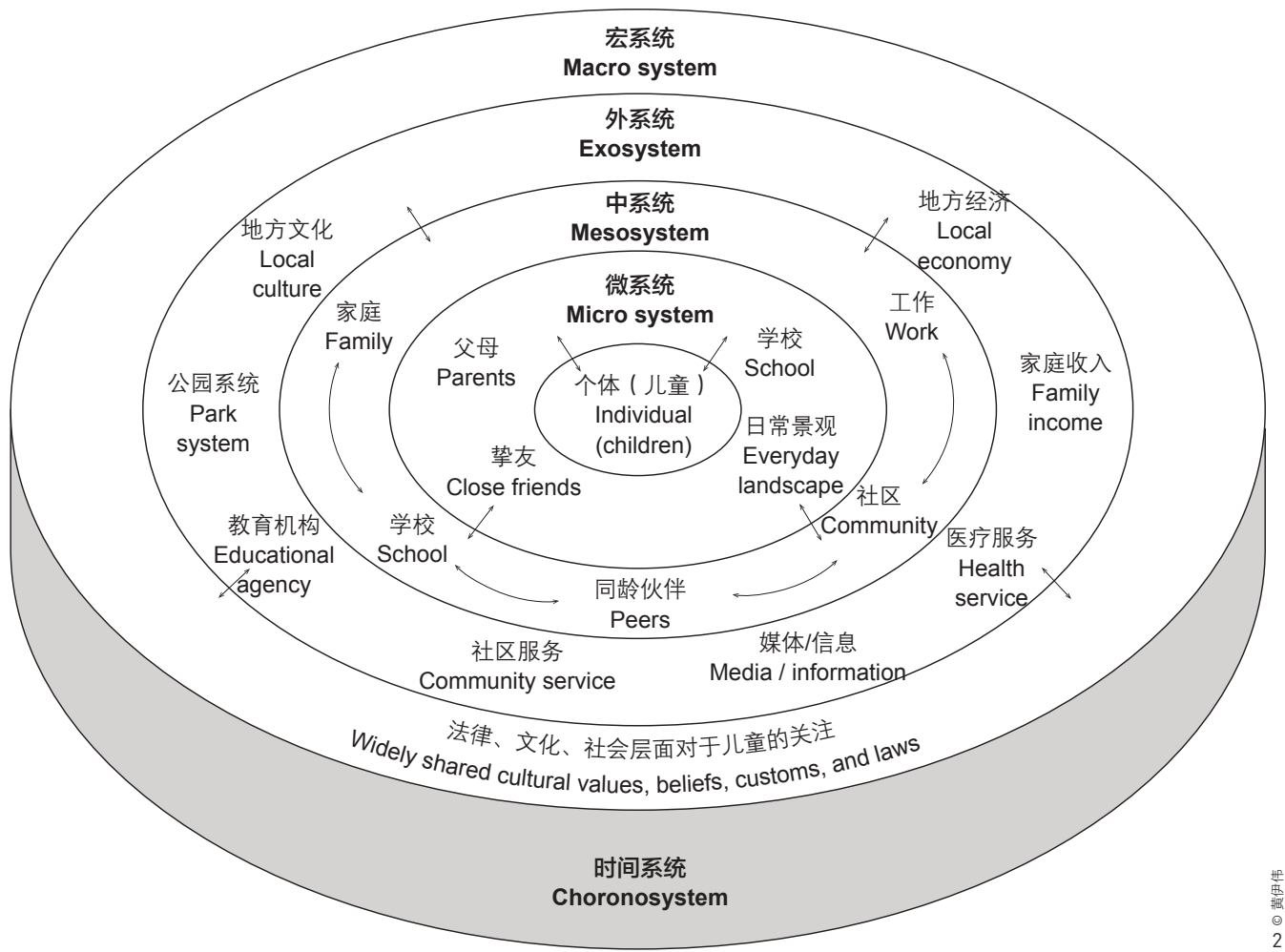

对儿童群体而言, 在生态系统理论中, 微系统是他们直接接触的 环境因子，一般包括家庭成员、同学、朋友，以及日常生活中最常接 触的景观（例如小区内的活动场地）; 中系统则是微系统各影响因子 之间的相互作用和关系 (如家庭住址会影响就读学校的选择、拥有怎 样的玩伴取决于儿童居住在怎样的社区）; 外系统包括但不限于当地 文化、医疗水平、公园系统、社区服务等，这些因子不会直接影响个 体，但会影响微系统和中系统的各个方面；宏系统则是更大层面的社会 或文化因素（如法律机制、亚文化、社会对下一代的关心程度等）。

生态系统理论对面向儿童的城市景观设计有以下几点启示：首 先，当前多数设计项目以微系统（如小区公园或游乐场）设计为主， 忽略了中系统、外系统乃至宏系统对儿童身心发展可能产生的深远影 响。景观设计师需要综合考量城市街道网络、空间格局、文化认同感 等因素，从而对城市儿童空间体系做出系统性优化。其次，需要进一 步借鉴其他学科的理论来指导景观设计, 例如根据环境心理学理论, 在学校内增加绿植可以促进儿童注意力的恢复 ${ }^{[0]}$; 恰当的居住区内建筑 及空间布局有助于形成良好的邻里关系 ${ }^{[11]}$; 通过优化街道设计降低城市 犯罪率 ${ }^{[12]}$ 等。最后, 景观设计学科需要与其他城市建设学科加强合作, 推动相关政策的更新和行业发展。 cultural factors of a broader societal and cultural influence, e. g., the legal system, subcultures, the public concerns for younger generations.

The Ecological Systems Theory would enlighten urban and landscape design for children in the following aspects: First, most contemporary projects focus more on the design of micro systems (e. g., community parks or playgrounds), thinking less of how to leverage the functionality of mesosystems, exosystems, and macro systems for children's physical and mental development. Landscape design should be conceived under a holism of street network, spatial pattern, and cultural identity, so as to improve a city's spatial system for children systematically. Second, theories adopted from other disciplines would benefit landscape design, with, for example, evidence from Environmental Psychology that proves greenery in schools directly promotes the recovery of children's attention ${ }^{[10]}$, findings on spatial arrangement of buildings that help enhance acquaintances relationship in neighborhood ${ }^{[11]}$, and evidence that a better street environment sees lower crime rate ${ }^{[12]}$. Finally, Landscape Architecture also needs to strengthen crossdisciplinary cooperation in urban construction to inform policy updates and propel profession advance. 


\section{2 公众参与理论}

公众参与是促进政府部门和开发单位与公众之间实现交流，同时 使公民参与决策过程的一种现代政治理论。它可以被理解为现代社会 公民的一种权利和责任。根据儿童友好型城市的建设目标和纲要，儿 童有权利作为公众的组成部分之一，与其余群体一起发声。景观设计 师可通过参与式设计 ${ }^{[13]}$ (图3) 推动儿童行使参与权。

儿童参与式设计策略在西方国家已非常普遍, 并体现出多重教育 意义和对儿童权益的保障作用, 如合作经历会增强儿童与青少年主动 解决问题的能力和信心，促使他们成为推动社会公平的重要力量; 儿 童参与环境规划、理解环境问题的过程会加强他们的社会责任感; 参与自己居住城市的公共空间决策和设计会增强其地方归属感 ${ }^{[14]}$ 等。 在中国儿童友好型城市的实践探索中, 这一策略亦有望发挥显著推动 作用。

\section{3 案例研究}

下文将通过三个案例, 具体阐释景观设计师在建立儿童友好型城 市中的角色。通过基于生态系统理论对项目影响进行多尺度考量, 以 及采用公众参与理论指导下的儿童参与式设计策略, 这些案例体现了 景观设计师社会职责和角色的突破及转变。

\section{1 “成长在博尔德” 计划}

2009年春, 美国科罗拉多大学博尔德分校的社区参与、设计与研 究中心 ( CEDaR) 发起了 “成长在博尔德” ${ }^{[15]}$ ( GUB ) 计划, 在科罗拉 多大学、博尔德市政府、博尔德谷学区、州参议员多萝西 - 鲁伯特、 当地非营利组织和企业, 以及18岁以下的儿童和青少年之间建立了合 作伙伴关系。GUB旨在将孩子们的意见纳入地方政府决策，尤其是在公 共空间设计、公交系统建设，以及住房规划等项目上。CEDaR的景观 教师和研究者们作为孩子们与其他利益相关方之间的交流媒介, 让他 们来定义自己理想中的城市, 并以自己的方式表达出来。

“15分钟的邻里” ${ }^{[16]}$ 是GUB计划的子项目之一, 其主要目标是建立 高度适宜步行的街区、鼓励混合用途开发，打造15分钟步行生活圈。 该项目的合作团队包括两位CEDaR代表（同时也是景观设计师）、5位 志愿者、一名实习生, 以及 25 名 $8 \sim 12$ 岁的儿童。这些儿童从各自的学 校或住所出发步行 15 分钟, 将沿途的交通问题及自己平时玩要的地点 告诉研究者, 并拍下他们喜欢的社区一隅的照片, 最后画出或用模型 制作出自己心目中的完美社区 (图4) 一一令人欣喜的是, 孩子们有 能力分辨街区的安全区域和危险区域, 这对儿童参与整个城市格局和 空间的设计将有很大帮助。景观设计师将孩子们提供的信息记录下来 作为设计参考, 并将这些信息转化为城市空间评估报告及改造方案, 提交给政府和开发商。在批准改造之后，景观设计师再次介人，听取 儿童对于改造方案的意见并进行修改, 最终实现 “属于儿童的设计” （图5）。一个个街区尺度的项目连接起来可以逐步改变城市空间脉

\subsection{Public Participation Theory}

Public participation is a modern political agenda that promotes citizens' involvement in decision-making process to enhance the communication and coordination between the government, developers, and the public. In a modern society, public participation is a right and a responsibility for all citizens, including children, of course. In the establishment of CFC, landscape architects can practice children's participation through participatory design ${ }^{[13]}$ (Fig. 3).

Children's participatory design has been widely practiced in western countries, which was proved quite educative and helpful to protect children and adolescent's rights and interests. For example, cooperative activities would enhance their problemsolving ability and confidence and encourage them to contribute to social equality issues; Engaging children in environmental planning can help them better understand environmental issues and increase their awareness of social responsibility; Participating in the decision-making and design processes of public spaces where they live would enhance their belongingness ${ }^{[14]}$. This strategy is promisingly critical to China's CFC establishment.

\section{Case Studies}

In this article, three cases are introduced to elaborate the responsibilities and roles of landscape architects in CFC establishment based on the two theories above.

\subsection{Growing Up Boulder Initiative}

In the spring of 2009, led by Community Engagement,

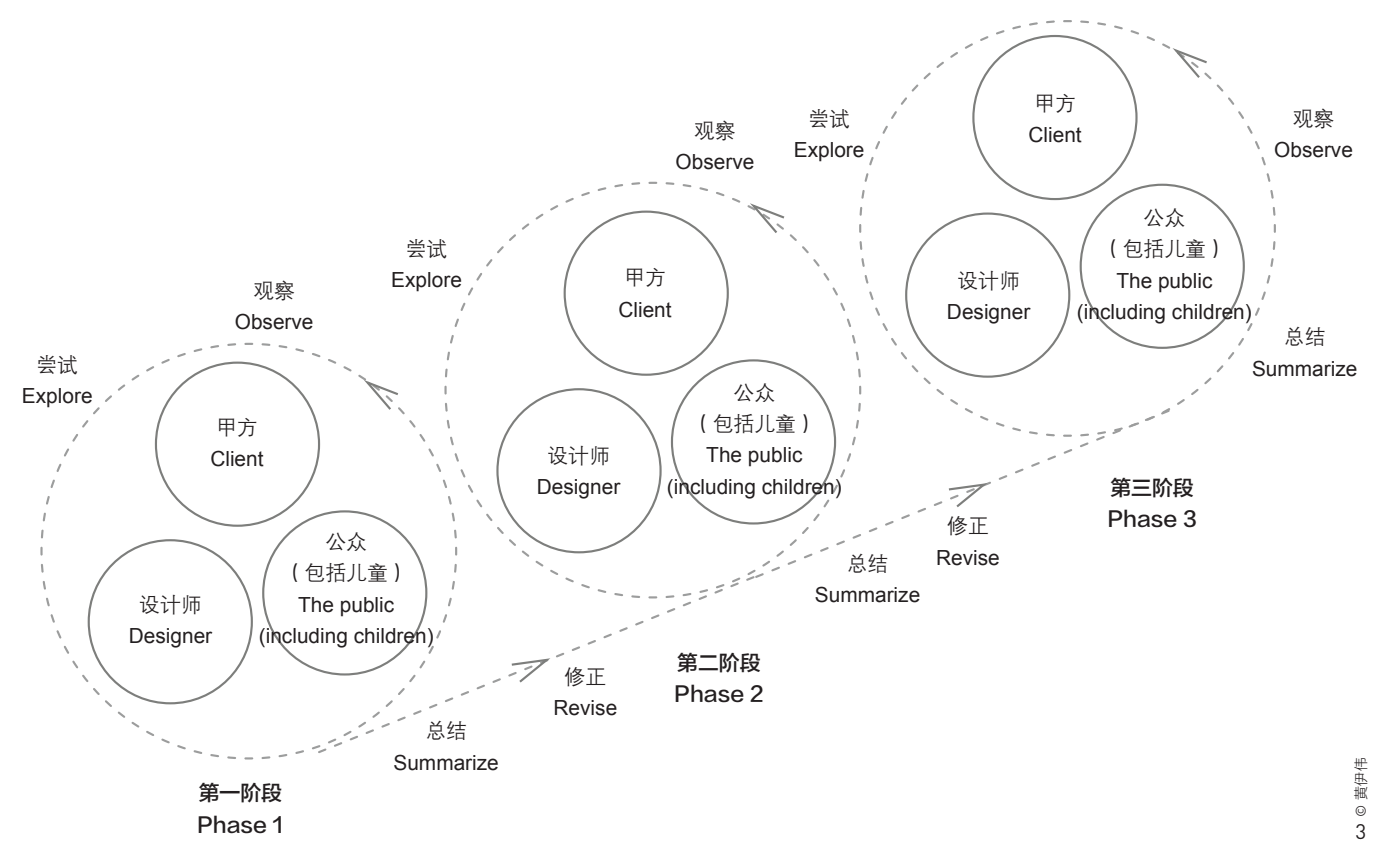


4. 在 $G \cup B$ 计划的子项目 “15分钟的邻里” 中, 当地小学生制作了包含 绿地、不同形式的建 筑、混合用途开发地块

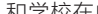
(上图); 老师和建豆 师在观看和解读孩子 制作的模型 (下图) ( 项目指导: 科罗拉多 大学博尔德分校)

5. GUB计划的城市空间整 改模式及景观设计师所 扮演的角色。

4. In "15-Minutes Neighborhoods" project of GUB, pupils made a model of their expected neighborhood including green spaces, different forms of use deve and a school labove) Teachers and architects were viewing and discussing the model (below). (Guided by University of Colorado Boulder

5. The mode of urban space improvement in GUB, showing the role landscape architects play in such practices.
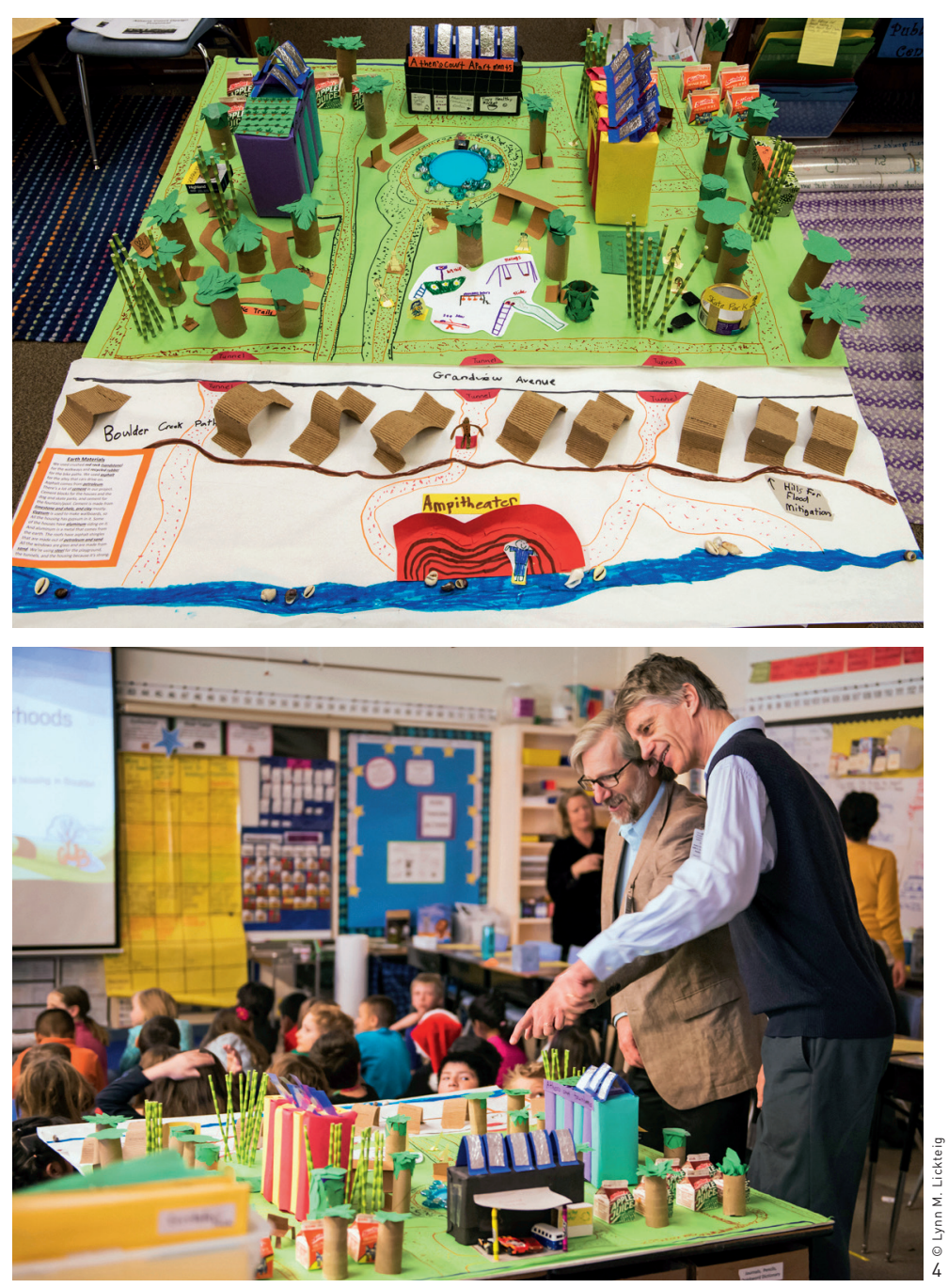

Design and Research Center (CEDaR), University of Colorado Boulder launched the Growth Up Boulder (GUB) Initiative, forming a partnership among the University of Colorado, the City government of Boulder, the Boulder Valley School District, State Senator Dorothy Rupert, local nonprofit organizations and businesses, and children and adolescents aged below $18^{[15]}$. GUB aims to incorporate children's opinions into local construction decisions on public space, public transportation systems, and housing planning. Landscape teachers and researchers from $\mathrm{CEDaR}$ act as an agent between children and other stakeholders, encouraging children's wild envision and expression about the "ideal city."

"15-Minute Neighborhoods" ${ }^{[16]}$ was one of the projects of GUB Initiative, aiming to establish highly walkable and mixeduse neighborhoods that provide all daily amenities within a 15 -minute walking distance. The project team consists of two GUB representatives (also landscape architects), 5 volunteers, and an intern together with 25 children aged from 8 to 12 years old. These children were required to walk for 15 minutes from schools or homes, report the traffic problems and the places they lingered or played on the way, take photos of the corners they liked in the community, and finally paint or model a community they desired (Fig. 4). In this process, it was impressive that children show a good ability to identify the safe or dangerous areas within the neighborhood which means it is practicable to involve them in the urban planning and design process. Taking the information and materials children provided for the record, landscape architects
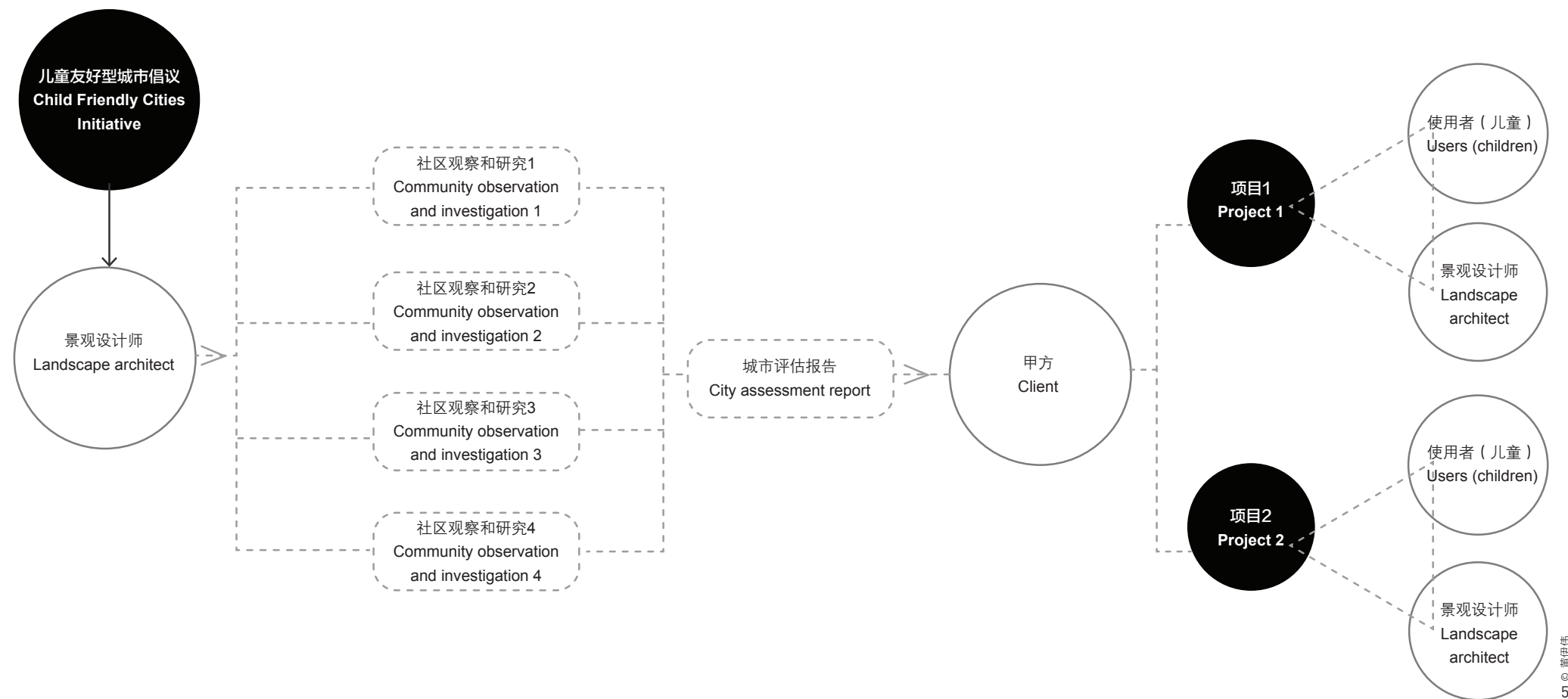
络, 进而优化城市格局; 景观设计师也在协调儿童参与者和政府关系 的过程中，成功引导决策者更加重视儿童的参与权。

\section{2 伦敦游乐和非正式娱乐策略}

2012年，伦敦市市长颁布了《塑造社区: 游乐和非正式娱乐》规 划指南 ${ }^{[17]}$, 其核心理念有两点, 一是规定了新开发住宅中游乐空间的最 低数量标准 $\left(20\right.$ 户及以上的开发项目至少要为每个孩子提供 $10 \mathrm{~m}^{2}$ 的游 乐空间）; 二是提出应当涵盖 “正式的”（游乐场等儿童专属娱乐场 地等) 和 “非正式的” (城市开放空间、公园、绿色基础设施等) 两 类游乐空间, 并详细阐述了如何在不同类别的空间中增加儿童友好型 设施, 如社区公园应该提供运动场地、儿童娱乐设施、休胍区和自然 区域; 口袋公园应提供自然化的活动空间, 配有足够的遮荫, 并尽可 能增加座椅和小型活动设施。该策略同时指出, 一个优质的游乐空间 需要提供面向全年龄段的、安全的、包容性强的娱乐设施, 同时具有

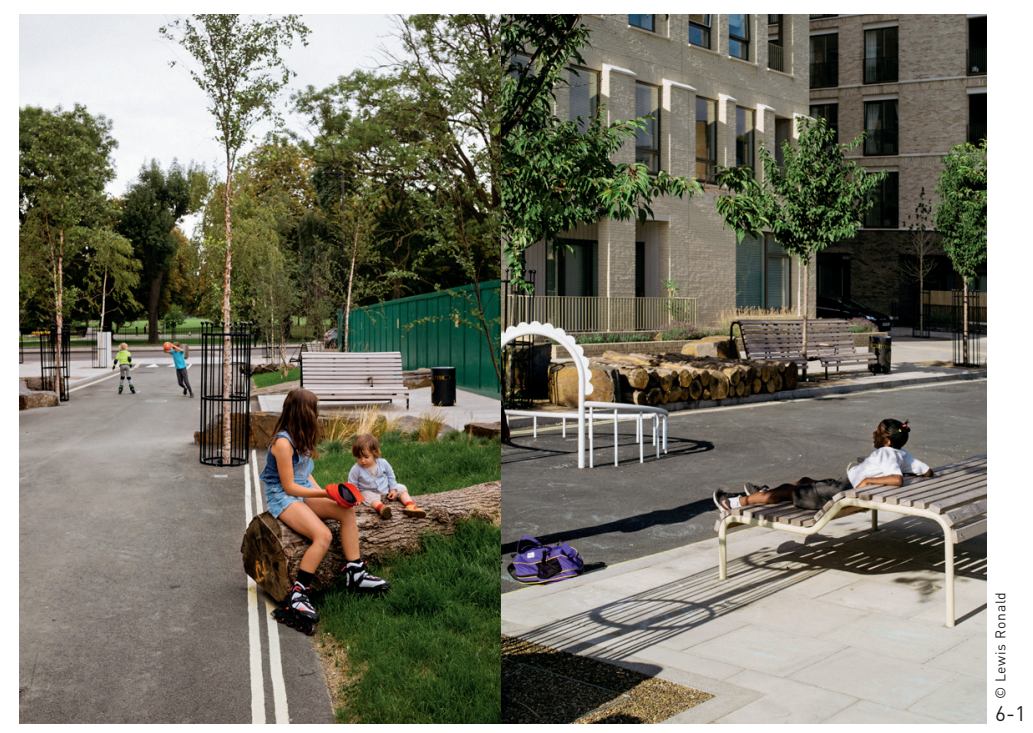

were able to evaluate the existing urban space system, and develop improvement proposals which can become formal actions after being approved by the government and developers. Then the approved proposals would be further improved by collecting children's feedback in order to truly realize a "design for children" (Fig. 5). As such projects are increasingly implemented in urban blocks, the spatial pattern of the whole city would be more friendly to children, through which landscape architects as coordinators have spurred decision makers paying more attention to children's participation.

\subsection{Play and Informal Recreation Strategy of London}

In 2012, London Play Strategy was proposed in a planning manual Shaping Neighborhoods: Play and Informal Recreation issued by the Mayor of London ${ }^{[17]}$, which not only stipulated that any new residential development of 20 households or more must provide each child with at least $10 \mathrm{~m}^{2}$ of amusement space, but also emphasized that both formal (the exclusive play spaces for children such as playgrounds) and informal (such as urban open spaces, parks, and green infrastructure) play spaces should be provided in the city, and elaborated how to locate child-friendly facilities in different space types. For example, community parks should provide sports venues, children amusement facilities, and relaxing and natural areas; Pocket parks should also provide flexible natural spaces for activities with adequate shade, and more seats and small facilities if possible. The strategy also highlighted that a highquality play space should be safe and inclusive to all users with good accessibility, management, and maintenance, promoting a
. 伦敦“游戏巷道”（设 计：Muf建筑/艺术设 计事务所）通过一系 列精心设计吸引儿童 前来嬉戏和社交, 同时 激发他们的相象力（图 激发他们的想象力 (图 6-1); 在伦敦伊夫林 法院项目 (设计: Erect 建筑事务所) 中, 设计 师在一个高密度住宅区 内利用地势高差建造了 一个公园, 串联起了原 本被高差隔断的住宅群 (图6-2)。
6. With a series of elaborate designs, Play Lanes (designed by Muf architecture / art) attracts children to play and communicate here, triggering imaginative behaviors (Fig. 6-1); In a high- density residential block in the Evelyn Court Project Idesigned by Erect Architecturel, landscape architects converted a piece of green space into a park to connect houses on different elevations (Fig. 6-2).

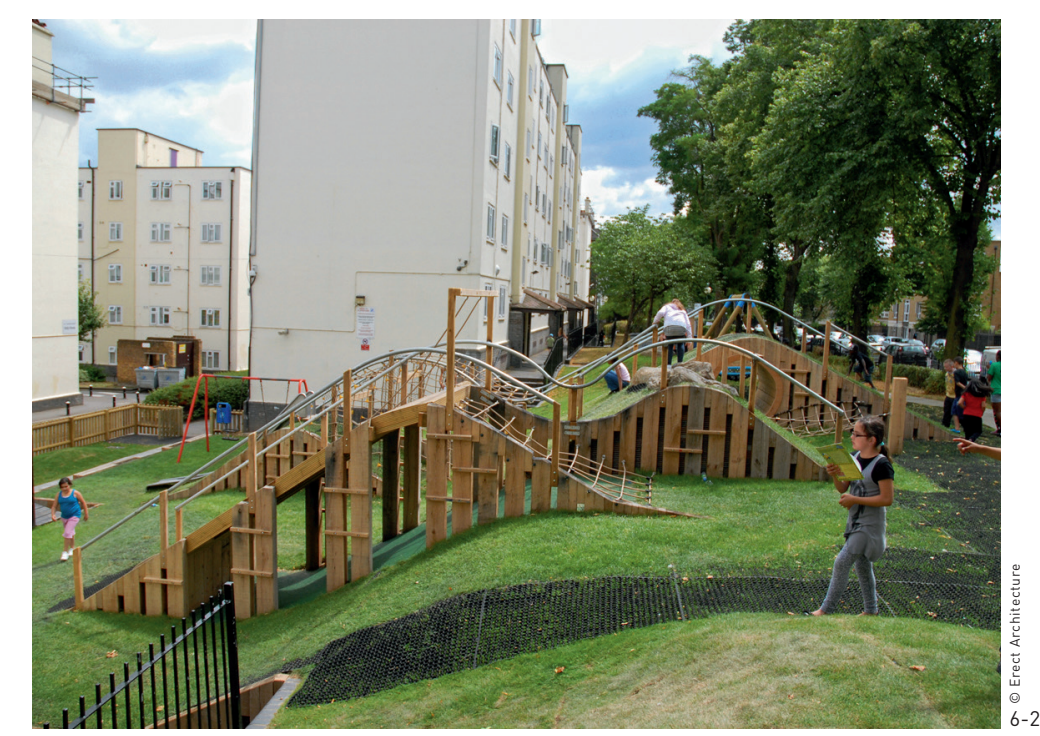


可达性强、管理维护良好等特点, 能够促进健康的生活方式, 让儿童 安全地亲近大自然 (图6)。

以规划指南为基础, 景观设计师经由详细踏勘各种类型的城市 口袋空间, 通过巧妙的设计, 大大提升了空间的趣味性。例如, 对绿 地鿒乏区域, 在树木周围安装围栏和攀爬装置, 使儿童乐意在此处逗 留、玩要; 在绿色基础设施建造过程中将雨水花园改造为可供儿童玩 要的 “雨水乐园” ; 在场地有限的校园内设置 “跑酷公园” , 通过设 置缩放墙壁、增加跳跃障碍物和形状不一的台阶等, 促进儿童体力运 动, 提高其肢体协调性。这些设计均通过小尺度的场地 ( 即 “微系 统” ) 干预, 使儿童游乐活动渗透到各类城市空间, 在城市尺度上提 升了伦敦市的儿童友好度。

在伦敦游乐与非正式娱乐策略的实施过程中, 景观设计师有意识 地将保障儿童游乐权利提升到优先地位, 在街区改造过程中与城市规 划师积极开展合作，了解各个街区内绿色空间的可达性、灵活性和多 样性。随后通过一系列微观项目设计, 打造了连续的儿童游乐空间网 络。微系统、中系统和外系统相互协调、互相补充, 在多级空间尺度 上系统性地优化了儿童游乐空间的供给 (图7)。同时, 自上而下渗透至 城市各个角落的游乐设计也更新了公众对于 “游乐空间” 的固有认知。

\section{3 美国绿色校园}

美国绿色校园 (GSA) ${ }^{[18]}$ 是一个由景观设计师、规划师莎朗・丹克 斯领导的非营利组织。该组织旨在将被沥青覆盖的校园空间改造为软 质绿地和花园, 从而提升儿童的身心健康水平、改善社区的生态绩效 及㓞性。在GSA看来, 一系列小型绿色空间可以成为城市绿色基础设施 网络和野生动植物栖息地网络的组成部分, 从而帮助改善城市空气质 量和局部气候。

在GSA的一系列实践中, 景观设计师不再是顾问, 而是积极寻找 城市和社区成员建造绿色校园的障碍, 消除这些困难并尝试建立新 工作范式 ${ }^{[19]}$ 。在 “建立和维持绿色校园的经验法则” 中, 他们通常先 对校长、学校委员会和学校教职员工进行教育宣传 ${ }^{[20]}$ 。通过 “提出案 healthy lifestyle and allowing children to explore the nature at will (Fig. 6).

Guided by the planning manual, landscape architects extensively investigated the city's pocket parks across London and enhanced their "playability" through elaborate designs. For example, in areas where green space was scarce, fences and climbing facilities around big trees were installed to attract children to play; rain gardens were transformed into playable ponds as part of the city's green infrastructure; and parkour parks were created in schools that lacked activity space, by setting scaling walls, obstacles for jumping, and steps in different shapes to increase children's physical activity and enhance their body coordination. By improving such small spaces, say, the micro systems for children, landscape architects have embedded children amusement into all types of urban spaces in London, making the city more childfriendly.

The implementation of the Play and Informal Recreation Strategy of London increases landscape architects' awareness of prioritizing and guaranteeing child's play right in urban space design. After a holism investigation on the accessibility, flexibility, and diversity of the city's green spaces, landscape architects have partnered with urban planners in neighborhood regeneration to improve the city-wide spatial system for children play (Fig. 7). In addition, through such a series of coordinated actions, citizens' understanding on "play space" has been refreshed.

\subsection{Green Schoolyard America}

Green Schoolyards America (GSA) is a non-profit organization in the United States led by landscape architect and planner Sharon Danks. It seeks to transform asphaltcovered school grounds into playable green spaces and gardens that contribute to children's physical and mental health, as well as the ecological performance and resilience of a community ${ }^{[18]}$. In GSA's vision, a series of small green spaces can be a part of the city's green infrastructure network and wildlife habitat network, thereby helping improve air quality and local climate.

In the practice of GSA, landscape architects are not subconsultants anymore; instead, they identify the barriers that prevent city and community members from building green schoolyards, disassemble these difficulties, and try to establish a new norm to follow ${ }^{[19]}$. According to their Rules of Thumb for Starting and Sustaining Green Schoolyards, they usually start with concept introduction to the principals, school committees, as well as school faculties ${ }^{[20]}$. The process 


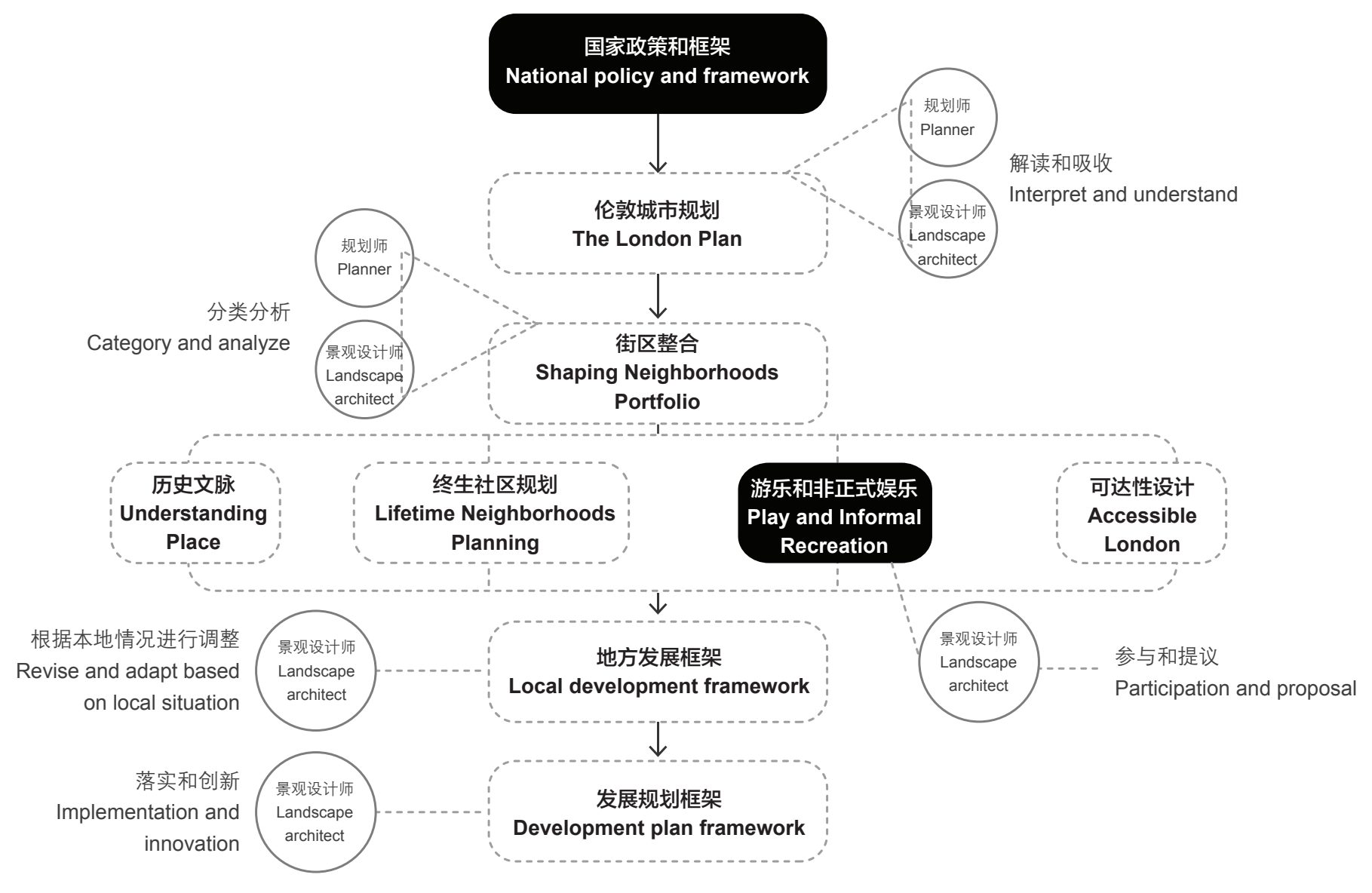

7. 伦敦游乐和非正式娱乐 策略的规划框架及景观 设计师所扮演的角色

7. The planning framework of the Play and informal Recreation Strategy of London, showing the role landscape architects play

例” “建立联系” “尝试理解” 的过程来真正了解客户的能力, 以便 提供其所缺乏的技术和资源来确保项目成功。在学区不愿支持大型校 园改造的情况下，他们将从一个小项目开始进行试点示范，并增加宣 传和外部讨论。当其他学校看到了景观改善带来的良好社会和环境效 益, 他们就也会相继加人, 从而引起更广泛的社会反响。

在过去的几年中, GSA 与加利福尼亚州奥克兰学区合作，直接促 成了当地教育委员会在全市建立绿色校园的愿景 ${ }^{[21]}$, 成为由非营利组织 汼头的景观改善计划的典型案例，并获得了政府的资金支持（图8）。 他们还与奥克兰学区以及公共土地信托中心的合伙人一起制定了名为 of "making a case," "connecting," and "understanding" is a public educational and communication progress, which allows them to really examine the capability of the client, as well as visioning the future skill sets still needed to make the project successful. In the cases when the district is reluctant to support a large schoolyard renovation, they would start with a small project as a pilot and increase publicity and external discussion. While other schools saw the social and environmental benefits brought by the landscape enhancement, they also joined in one after another, which in turn produced a wider social response.

In the past few years, GSA has greatly contributed to the vision developed by the education committee of Oakland Unified School District in California to promote green schoolyards throughout the city ${ }^{[21]}$, establishing a paradigm of landscape improvement programs led by non-profit organizations with government funding support (Fig. 8). GSA, Oakland Unified School District, and the partner at the Trust for Public Land also jointly issued a school board policy called "Living Schoolyard" that aims to improve the design standards 
8. GSA在加利福尼亚州 奥克兰市的试点项目 之一: 胡佛小学校园 改造。( 项目指导: GSA)

9. GSA的运行框妿及景观 设计师所扮演的角色

8. One of GSA's pilo projects in Oakland California: the improvement of schoolyard of Hoove Elementary School IGuided by Green Schoolyards Americal . The operating framework of GSA, showing the role landscape architects play in this practice.

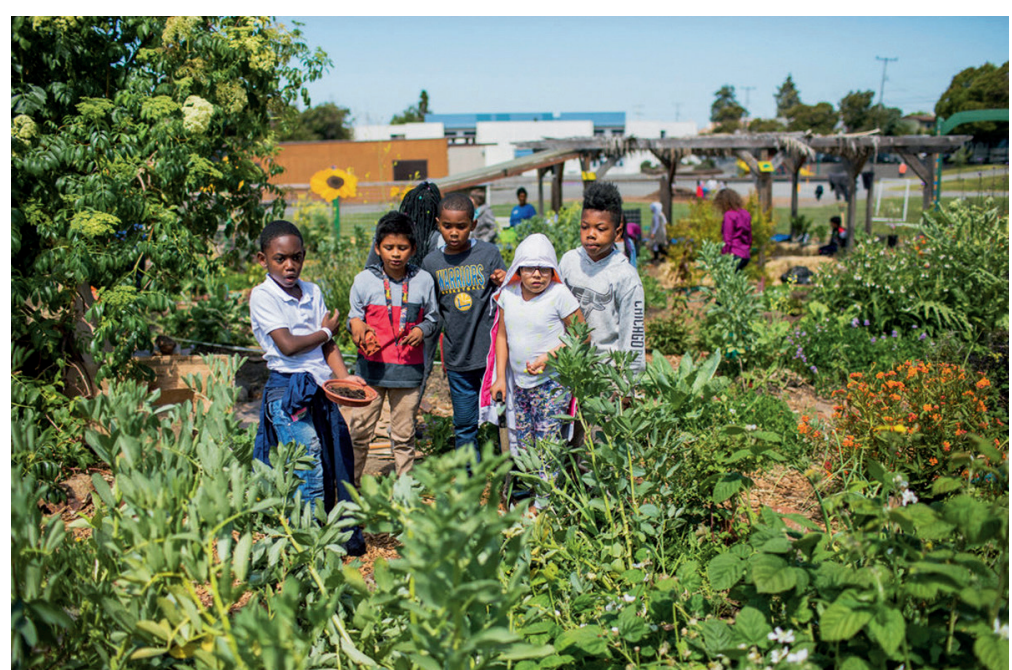

“生机勃勃的校园” 的校园空间改造政策，以期改变城市中所有校园 空间的设计标准。在GSA的实践中，景观设计师已不再只是甲方的代理 人，而是城市景观改造项目的发起者和领航者（图9）。

\section{4 景观设计师的职责转变}

在以上三个案例中, 景观设计师的角色和职责不尽相同, 但都直 接或间接地推动了当地儿童友好型城市的建设。

在GUB项目中，景观设计师的角色是利益协调者，通过将甲方与 儿童使用者的不同意见进行协调、整合，间接保障了儿童利益。GUB

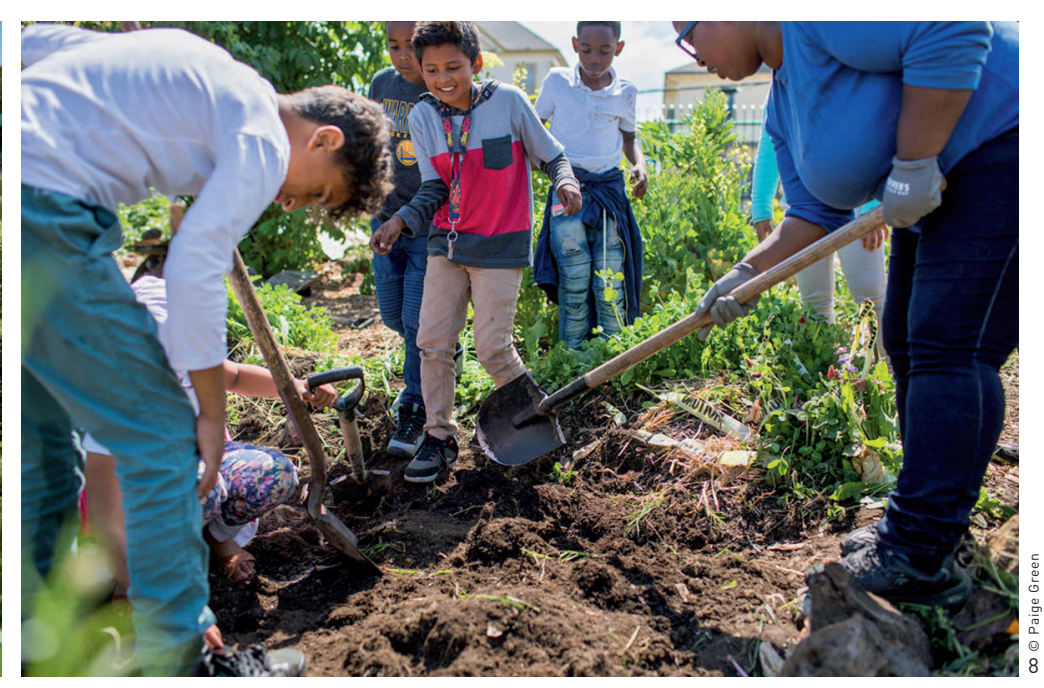

of schoolyards across the city. In this program, landscape architects no longer only work for satisfying the clients' requirement, but become the initiator and leader of urban landscape transformation (Fig. 9).

\subsection{Responsibilities and Roles of Landscape Architects}

The three cases above all demonstrate the roles and responsibilities of landscape architects in promoting CFC establishment at local scale.

In GUB's practice, landscape architects serve as intermediaries who respond to children's demands and desires and coordinate them with other stakeholders', indirectly protecting child rights and interests. Louise Chawla, one of

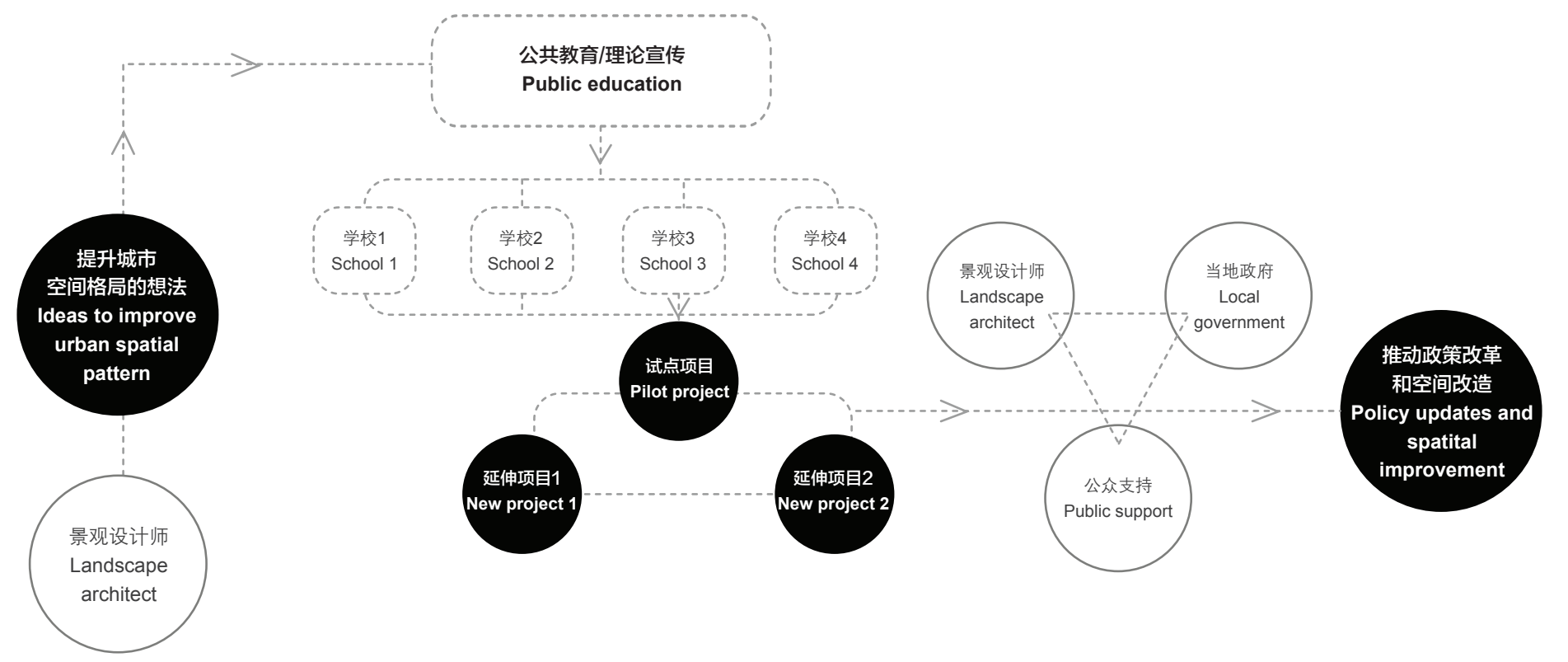

量


的创始人之一、科罗拉多大学博尔德分校环境设计系教授露易丝・查 拉认为, 建立属于孩子们的空间, 就一定要倾听孩子们的声音。而景 观设计师存在的意义即在于将孩子的语言转变为设计语言、将孩子的 诉求转化为便于决策者施行的城市改造策略。这一思想有力地挑战了

“景观设计师是最懂场地的人” “景观设计师最有设计话语权”等传 统观念。

而在伦敦游乐策略的制定与落实中, 景观设计师承担着 “科学发 展顾问” 的角色。他们首先梳理规划框架的核心理念, 达成 “儿童优 先” 的共识, 随后与规划师一起进行绿地空间的分配与整合, 最后在 具体项目的落实中积极与公众对话, 成为不同群体之间的粘合剂。

GSA的发展模式则体现了景观设计师 “公众教育家” 的身份——宣 扬自然游乐的理念以及改善儿童游乐环境的益处。在这一模式中, 景 观设计师不依赖政府或私人委托承接项目, 而是主动寻找 “甲方” , 不断扩大社会影响。 the founders of GUB and a professor of the Department of Environmental Design at the University of Colorado Boulder, believes that to create a space for children, designers must listen to children's own voices. The significance of landscape architects lies in transforming children's ideas and demands into pragmatic urban space improvement strategies which are easy for decision-makers to implement, thus enhancing children's participation and communication with other stakeholders. This idea strongly challenges the conventional knowledge that "landscape designers know the site best" and "landscape designers have the most say in design."

In the London case, landscape architects play a role of urban development consultants. They replenish the core ideas of the city's planning framework with a consensus of "children first" and re-plan the green spaces together with urban planners through integrative design. Also, by emphasizing public participation in specific implementations, landscape architects bond different user groups for a maximum social benefit.

The practice of GSA reflects that landscape architects can act as "public educators," popularizing the concept of natural play and the benefits of improving children's play environment, as well as actively seeking clients and funding sources to expand the social impact of their values and ideas.

In these three cases, landscape architects have a common
10. 景观设计师通过承担不同 角色与职责完成城市儿童 空间的串联和组合。

10. Landscape architect's roles and responsibilities in connecting and integrating urban spaces for children

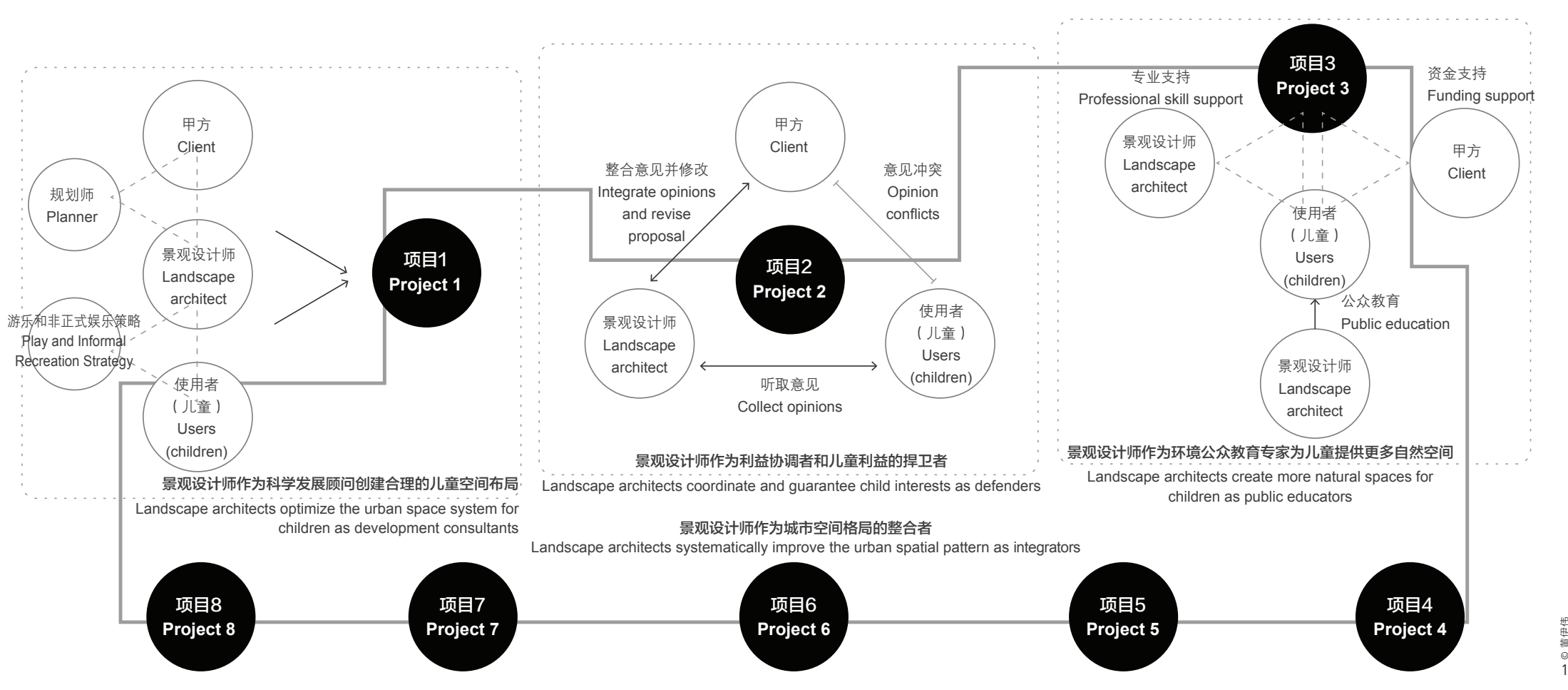


在这三个项目中, 景观设计师有一个共同的身份——城市空间格 局的整合者。他们并未将工作内容限定于传统的儿童游乐空间，而是 关注社区 (中系统) 和整个城市 (外系统) 的空间格局, 甚至在宏系 统层面推动了整个社会对儿童权利的重新审视, 最终完成了城市空间 的串联、整合与整体提升（图10）。

\section{4 结语}

詹姆斯・科纳曾说, 景观设计师若要夺回自己的话语权, 就要跳 出 “辅助支持” 的常态, 承担真正的领导职责, 变得更加批判、更加 进取、更加具有企业家精神、更具创造力 ${ }^{[22]}$ 。在儿童友好型城市的建设 过程中, 景观设计师不仅仅是设计策略的制定者, 亦可充当利益相关 方的协调者和参与式设计项目的发起者, 让 “儿童友好” 理念渗透到 城市的各个角落。LAF identity - integrators who improve urban spatial pattern. They do not limit their work to the design of traditional children playgrounds, but focus on upgrading communities (mesosystem) and the spatial pattern of the city (exosystem), increasing the society's attention to child rights at the macro system level and realizing an integration and improvement of urban spaces (Fig. 10).

\section{Summary}

James Corner said that if landscape architects want to regain their right of speech, they need to step out of the "assistance support" state and bear more responsibility, becoming more critical, more aggressive, more entrepreneurial, and more creative ${ }^{[2]}$. It is the same with the CFC establishment, where landscape architects should not just design proposals, but act as coordinators among different parties and leaders of innovative urban space renovation to perpetuate childfriendliness into every corner of city spaces. LAF

\section{REFERENCES}

[1] Arnstein, S. R. (1969). A ladder of citizen participation. Journal of the American Institute of planners, 35(4), 216-224.

[2] Davidoff, P. (1965). Advocacy and pluralism in planning. Journal of the American Planning Association, 31(4), 277296.

[3] Moore, R. C., Goltsman, S. M., \& lacofano, D. S. (Eds.). (1997) Play for all guidelines: Planning, design and management of outdoor play settings for all children (Second Edition). Berkeley: MIG Communications.

[4] UNICEF. (1989). Convention on the Rights of the Child. Retrieved from https://ohchr.org/Documents/ Professionallnterest/crc.pdf

[5] Francis, M., \& Lorenzo, R. (2006). Children and city design: proactive process and the renewal of childhood. In C. P. Spencer, \& M. Blades (Eds.), Children and their environments: Learning, using and designing spaces. Cambridge: Cambridge University Press.

[6] UNICEF. (n. d.). What is the Child Friendly Cities Initiative? Retrieved from https://childfriendlycities.org/what-is-thechild-friendly-cities-initiative/

[7] UNICEF. (2019, July). Shaping urbanization for children A handbook on child-responsive urban planning [Chinese version].

[8] Engel, G. L. (1977). The need for a new medical model: a challenge for biomedicine. Science, 196(4286), 129-136. doi:10.1126/science. 847460

[9] Bronfenbrenner, U. (1979). The ecology of human development: experiments by nature and design. Cambridge: Harvard University Press.

[10] Taylor, A. F., Kuo, F. E., \& Sullivan, W. C. (2001). Coping with ADD: The surprising connection to green play settings. Environment and behavior, 33(1), 54-77. doi:10.1177/00139160121972864

[11] Appleyard, D. (1980). Livable streets: protected neighborhoods? The ANNALS of the American Academy of Political and Social Science, 451(1), 106-117. doi:10.1177/000271628045100111

[12] Michael, S. E., Hull, R. B., \& Zahm, D. L. (2001). Environmental factors influencing auto burglary: A Environmental factors influencing auto burglary: A
case study. Environment and Behavior, 33(3), 368-388. case study. Environment and Beh
doi:10.1177/00139160121973034

[13] Hester, R. T. (2006). Design for ecological democracy (p. 509). Cambridge: MIT Press.

[14] Francis, M., \& Lorenzo, R. (2002). Seven realms of children's participation. Journal of Environmental psychology, 22(1-2), 157-169.

[15] CEDaR of University of Colorado Boulder. (n. d.). Growing Up in Boulder. Retrieved from https://www.colorado.edu/cedar/ current-projects/growing-boulder

[16] Mintzer, M., Mendoza, J., Chawla, L., \& Dellepiane, A. (2016,
September). Growing Up Boulder: Young People's Ideas for 15-Minute Neighborhoods. Retrieved from https://www. colorado.edu/cedar/sites/default/files/attached-files/15 min_neighborhood_report.pdf

[17] Sanson, H., Carlsen, J., \& Newitt, M. (2012, September). Shaping Neighbourhoods: Play and Informal Recreation Supplementary Planning Guidance. Retrieved from https:// www.london.gov.uk/sites/default/files/osd31_shaping_ neighbourhoods_play_and_informal_recreation_spg_high res_7_0.pdf

[18] Green Schoolyards America. In. d.). Green Schoolyards America. Retrieved from http://www.greenschoolyards.org/

[19] Iversen, L. (2020, February 6). Green Schoolyards: An Interview with Sharon Danks, Part 1. Retrieved from https:// thefield.asla.org/2020/02/06/green-schoolyards-aninterview-with-sharon-danks-part-1/

[20] Danks, S. G. (2010). Asphalt to ecosystems: Design ideas for schoolyard transformation. New York: New Village Press.

[21] Coastal Conservancy. (2017, September 28). Living Schoolyards for Oakland Project [Project No. 17-019-01]. Retrieved from https://scc.ca.gov/webmaster/ftp/pdf/ sccbb/2017/1709/20170928Board15_Living_Schoolyards.pdf

[22] Weller. R. [2019). In conversation with James Corner. LA+ Interdisciplinary Journal of Landscape Architecture, (9), 90-100. 